PRACE NAUKOWE UNIWERSYTETU EKONOMICZNEGO WE WROCLAWIU

\author{
Jacek Soltys, Anna Golędzinowska \\ Gdańsk University of Technology \\ e-mail: jsoltys@pg.gda.pl, a_g@tlen.pl
}

\title{
INTEGRATED DEVELOPMENT PLANS \\ OF THE FUNCTIONAL URBAN AREAS \\ IN POMERANIAN REGION IN POLAND
}

\section{ZINTEGROWANE PLANY ROZWOJU \\ FUNKCJONALNYCH OBSZARÓW MIEJSKICH W WOJEWÓDZTWIE POMORSKIM W POLSCE}

DOI: $10.15611 /$ pn.2017.476.03

\begin{abstract}
Summary: The European Commission put a growing emphasis on the territorial and integrated approach to policy support addressed in the frame of regional policy. In a special way this process refers to cities along with their functional environment. In Poland the National Spatial Development Concept 2030 has introduced the concept of functional areas, among others - Functional Urban Areas (FUAs). There is also a new tool - Integrated Territorial Investment (ITI) - for FUAs in the EU programming perspective of 2014-2020. The scope of the article includes FUAs of regional and sub-regional centers in Pomeranian Voivodeship. The objectives of this paper are: to identify the diversity of projects planned for FUAs; to identify factors that integrate the projects mentioned above. The following main methods have been applied: analysis of documents; typology of projects proposed for implementation concerning their subject and integrating factors. Territorial agreements basing on regional operational program were a formula of development planning in the researched FUAs, more liberal than the formula of ITI. In 95\% projects integrating factors can be identified (as hypothesis) and classified. The projects relate to many fields, the most to energy efficiency, health and transport.
\end{abstract}

Keywords: functional urban areas, integrating factors, Integrated Territorial Investment, Pomeranian voivodeship, typology.

Streszczenie: Komisja Europejska kładzie rosnący nacisk na terytorialne i zintegrowane podejścia do polityki wsparcia prowadzonej w ramach polityki regionalnej. W Polsce Koncepcja Przestrzennego Zagospodarowania Kraju 2030 wprowadziła pojęcie obszarów funkcjonalnych (FUA), m.in. miejskich obszarów funkcjonalnych (MOF). Wprowadzono też dla MOF nowe narzędzie dla okresu programowania w UE 2014-2020 - zintegrowane inwestycje terytorialne (ZIT). Przedmiotem artykułu są FUA ośrodków regionalnych i subregionalnych w województwie pomorskim, natomiast celami: poznanie zróżnicowania projektów planowanych dla FUA; rozpoznanie czynników, które integrują te projekty. Jako główne metody zastosowano: analizę dokumentów; typologię projektów z punktu widzenia ich rodzaju i czynników integrujących. Zintegrowane umowy terytorialne bazujące na regionalnym programie operacyjnym były formułą planowania projektów w badanych FUA, 
jako bardziej liberalne niż ZIT. W 95\% projektów można rozpoznać (jako hipotezy) i sklasyfikować czynniki je integrujące. Projekty dotyczą wielu dziedzin, najwięcej: efektywności energetycznej, ochrony zdrowia i transportu.

Słowa kluczowe: funkcjonalne obszary miejskie, czynniki integrujące, zintegrowane inwestycje terytorialne, województwo pomorskie; typologia.

\section{Introduction}

The European Commission put a growing emphasis on the territorial and integrated approach to policy support addressed in the frame of regional policy. In a special way this process refers to the cities along with their functional environment. According to the Common Provisions Regulation, the integrated territorial strategies are necessary to achieve smart, sustainable and inclusive Europe anticipated in the strategy "Europe 2020". To enable effective implementation of such strategies the document introduces a new tool - Integrated Territorial Investment (ITI), which provides a flexible mechanism for formulating an integrated response to various territorial needs, without losing focus on the theme, through which cohesion policy is associated with the strategy "Europe 2020".

This new approach at European level is in line with new solutions used at national level of planning in Poland. The National Spatial Development Concept 2030 (NSDC 2030) has introduced the idea of Functional Areas, among others, Functional Urban Areas (FUAs). The preparation of Strategy and Development Plan for Metropolitan Areas and FUAs of other capitals of voivodeships (regions) is mandatory, for FUAs of regional centres is recommended, for FUAs of sub-regional centres ( $>50$ thousands inhabitants) is described by NSDC 2030 as possible, for FUAs of local centres is described by NSDC 2030 as "lack of need" [Koncepcja... 2011, p. 185].

There is also a new tool - Integrated Territorial Investment (ITI) - for functional urban areas in the perspective of EU programming 2014-2020. The use of ITI is mandatory for all functional urban areas of voivodeship (regional) capitals and optional for others functional urban areas, depending on the decision of voivodeship authorities [Zasady... 2013].

These new solutions are barely reflected in literature, due to the short period since the beginning of their implementation. The article mainly concerns the description and analysis of integrated territorial approach, detecting or anticipated problems, but it does not relate to the use of these solutions in planning practice [Noworól, Domański 2013; Słodowa-Hełpa 2013; Zakrzewska-Póltorak 2013; Obrębalski 2014]. The first articles concern practice experiences start to appear [Rosenkiewicz 2012; Ratuszniak, Struś 2014; Frankowski, Szmytkowska 2015; Szafranek 2015].

The objectives of this paper are: (1) to identify the diversity of integrated projects planned for the functional urban areas; (2) to identify factors that integrate the projects mentioned above. As due to the new approach (the projects for the period 2014-2020 were called integrated) a question appears which factors integrate the 
projects. This approach is based on investments from the European Social Fund, the European Regional Development Fund as well as the Cohesion Fund under more than one priority axis of one or several operational programs. The goal of ITI is to implement territorial strategies by enabling coordination of funding from different sources, which was not fully possible before 2014 [Europe 2020... 2010; Ratuszniak, Struś 2014]. However, this is not the only aspect of integrated approach. As ITI requires the agreement of neighbouring local governments, integrating factors should be the main criterion for the implementation of particular project.

The scope of the study includes eight FUAs of the Pomeranian Voivodeship (apart from the Metropolitan Area of Gdańsk-Gdynia-Sopot) that is FUAs regional, sub-regional and some local centres.

The following methods have been applied: (1) analysis of planning documents, (2) typology of projects proposed for implementation (concerning the subject and integrating factors), (3) simple statistical analysis of projects - according to the subject and integrating factors.

\section{Functional urban areas and formulas of planning their development}

In June 2014 Integrated Territorial Agreement (ITA) was signed in Pomeranian Voivodeship (PV) between the Pomorskie Voivodeship Board (PVB) and representatives of 7 FUAs (Figure 1, Table 1). In October 2014 another agreement

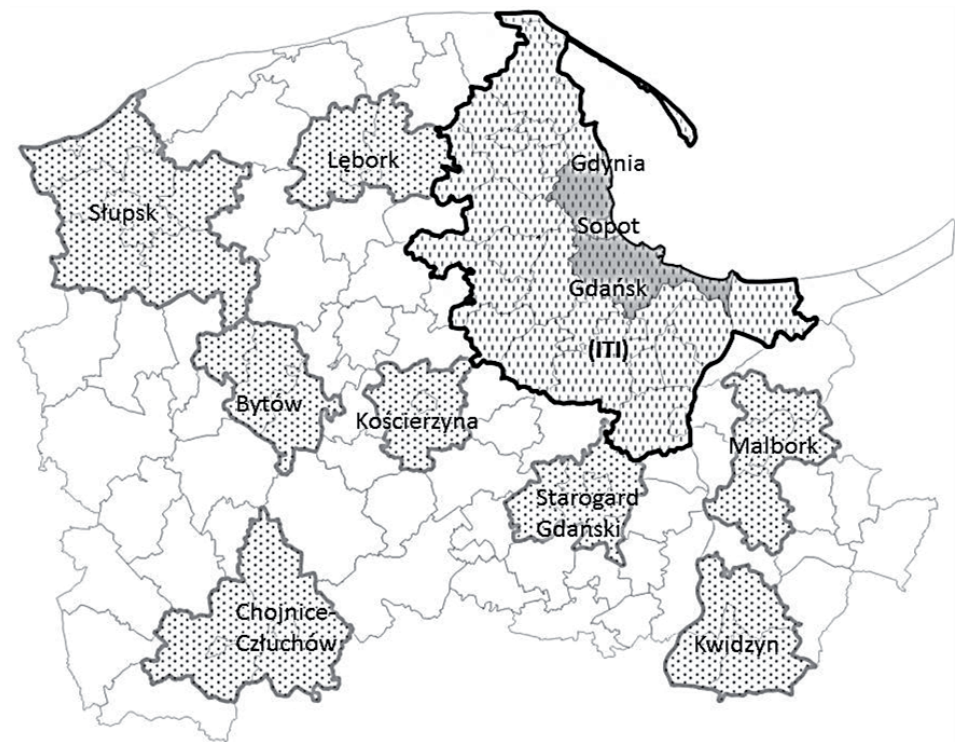

Figure 1. Location of Functional Urban Areas in the Pomeranian Voivodeship

Source: authors' own elaboration 
Table 1. Characteristic of FUAs in the Pomeranian Voivodeship in 2014

\begin{tabular}{|l|c|c|c|c|}
\hline \multicolumn{1}{|c|}{ FUA } & $\begin{array}{c}\text { Number } \\
\text { of gminas } \\
\text { (communities) }\end{array}$ & $\begin{array}{c}\text { Population } \\
\text { of FUA } \\
\text { in thousand }\end{array}$ & $\begin{array}{c}\text { Population } \\
\text { of core } \\
\text { in thousand }\end{array}$ & $\begin{array}{c}\text { Areas } \\
\text { in } \mathrm{km}^{2}\end{array}$ \\
\hline Bytów & 3 & 31 & 15.0 & 482 \\
\hline Chojnice-Człuchów & 4 & 83 & Chojnice 40.1 & 853 \\
\cline { 3 - 4 } & 2 & Człuchów 14.2 & \\
\hline Kościerzyna & 4 & 39 & 23,7 & 327 \\
\hline Kwidzyn & 3 & 64 & 11,2 & 534 \\
\hline Lębork & 5 & 61 & 35,4 & 521 \\
\hline Malbork & 6 & 152 & 39,0 & 492 \\
\hline Słupsk & 3 & 67 & 93,2 & 944 \\
\hline Starogard Gdański & & & 48,3 & 272 \\
\hline
\end{tabular}

Source: authors' own elaboration based on Central Statistical Office - Local Data Bank.

was signed with the representation of the FUA of Kościerzyna. The cores of analyzed FUAs are mainly medium-sized towns (20-100 thousand inhabitants). The largest of them is Słupsk - a former capital of voivodeships. In the group of core centres there are also two small towns (below 20 thousand of inhabitants): Człuchów (together with Chojnice of approximately 40 thousand inhabitants) and Bytów.

\section{Typology of projects proposed for implementation}

The negotiations on the content of ITA were difficult as gminas wanted to spend almost all of the fund on the improvement of local roads. The authorities of the voivodeship preferred other projects in such fields as: preventive health care, renewable energy sources, improvement of professional qualifications. As a result of agreements between the representatives of 8 FUAs and PVB 61 projects were approved (Table 4).

Two typologies of the projects were done, concerning: (1) integrating factors, (2) subjects. Types of integrating factors were established on the basis of analyzing the following issues for each project:

1. Whether the project is located in one or in several gminas.

2. If the project is located in several gminas, if it actually indivisible or if it can be implemented as several projects in each gmina separately? If so, what (factor) can cause the connection?

3. If the project is located in one gmina, what does connect it with other gminas?

As a result of the response to the above questions the following typology of integrating factors was obtained: 
$\mathrm{SE}^{1}$ - the spatial extent (located in more than one gmina),

$\mathrm{SR}$ - network - systemic relations,

$\mathrm{RC}$ - range of service - centre (central functions),

$\mathrm{RI}$ - range of influence - others (ex-resource base of the object),

$\mathrm{SO}$ - specialized contractor, usually located in the center of the area or external; the inclusion of a wider project area usually increases the efficiency of the project,

ST - the same type of project - integration of several projects into one and commitment of one contractor, which raises the project's efficiency (as above);

? - integrating factor is difficult to discover; the project concerns one gmina, and its impact on the surrounding area is doubtful.

The subjects of projects were divided into following types:

Ed - education,

$\mathrm{H}$ - health (including E-health),

I - ICT (information and communication technologies),

$\mathrm{SE}$ - social economy, vocational activation, social activation,

$\mathrm{Tr}$ - transport,

En - energy efficiency - including: thermal energetics and thermomodernization,

WoM - technical infrastructure - waste management,

WaM - water management.

List of projects in PV and their types according to integrating factors and subjects are presented in Table 2 (similar names of some projects have been unified).

The analysis of the projects according to types of integrating factors and types of subjects has been carried out. Their share in the total number of projects (in \%) has been calculated (Tables 3,4). Table 4 shows that integrating factors were doubtful only in case of 4 projects. For $93 \%$ of projects these factors have been possible to discover as a hypothesis. Table 4 shows that projects relate to many subjects. The highest share of projects (about 1/4) concerns energy-efficiency (especially thermal energetics). The second highest number of projects (18\%) concerns health. The share of transport-related project is below $15 \%$. High variety of subjects can be considered as a great effect of negotiations between representatives of FUAs and PVB.

The issue of delimitation is worth further analysis and discussion. Projects related to the central functions in core area (hospitals, universities) serve usually much greater the area than FUA - the whole poviat, or in the case of the hospitals with reference level II and universities - even a broader area (mostly over 2 poviats). The criterion for the delimitation of functional areas of this type would be completely different than the one which was used. It also seems to be incorrect to delimitate smaller FUA's according to the same criteria such as for voivodeship capitals. Others FUAs of non-metropolitan character have problems of different specificity. Discovered integrating factors do not arise from advanced urbanization processes.

\footnotetext{
${ }^{1}$ Symbols are used in Table 2.
} 
Table 2. List of projects in the Pomeranian Voivodeship and their types according to integrating factors and subjects

\begin{tabular}{|c|c|c|c|}
\hline $\begin{array}{l}\text { Inte- } \\
\text { grating } \\
\text { factor }\end{array}$ & $\begin{array}{l}\text { Subject } \\
\text { of project }\end{array}$ & Projects & FUA/ITA \\
\hline SE & NLP & $\begin{array}{l}\text { Preservation of natural and landscape values of the ecological corridor } \\
\text { of the Wierzyca valley }\end{array}$ & SG \\
\hline SE,SR & WoM & Small retention of the Liwa river & $\mathrm{Kw}$ \\
\hline \multirow[t]{9}{*}{ SR } & WoM & Rainwater and snowmelt management along with water retention & B CC K M SG \\
\hline & $\operatorname{Tr}$ & $\begin{array}{l}\text { Construction of nodes integrating subsystems of individual and public } \\
\text { transport }\end{array}$ & B CC S L SG \\
\hline & & as above $\&$ revitalization of the historic railway station & $\mathrm{Kw}$ \\
\hline & & as above $\&$ local nodes and infrastructure for bicycle transport & $\mathrm{K}$ \\
\hline & & Improvement of accessibility to public transport stops & M \\
\hline & & Construction of the roads connection & $\mathrm{B}$ \\
\hline & I & Implementation of interoperable information systems & $\mathrm{L}$ \\
\hline & $\mathrm{I}, \mathrm{H}$ & E-health system & $\mathrm{CC} \mathrm{M}$ \\
\hline & & $\begin{array}{l}\text { Internet access services enabling the implementation of the e-health } \\
\text { system }\end{array}$ & $\mathrm{S}$ \\
\hline \multirow[t]{11}{*}{$\mathrm{RC}$} & $\mathrm{H}$ & Informatization of the Independent Public Healthcare & $\mathrm{CC}$ \\
\hline & & Development of the long term care and telecare & $\mathrm{CC}$ \\
\hline & & Development of the psychiatric treatment infrastructure & $\mathrm{CC}$ \\
\hline & & Establishment of diabetes unit at the hospital in Chojnice & $\mathrm{CC}$ \\
\hline & & Development of poviat hospital & M \\
\hline & & Improving patient's safety and effectiveness of services & $\mathrm{B}$ \\
\hline & & Improving access to health services of poviat hospital & $\mathrm{B}$ \\
\hline & & Improving access to health service & $\mathrm{K}$ \\
\hline & Ed & Shaping the projection of higher education & $\mathrm{CC}$ \\
\hline & & Słupsk Academic Center - practical profile education & $\mathrm{S}$ \\
\hline & $\mathrm{S}$ & The space of the Pomeranian Academy and the City of Słupsk & $\mathrm{S}$ \\
\hline \multirow[t]{4}{*}{ RI } & TR & Construction Sailing Center in Ustka & $\mathrm{S}$ \\
\hline & & Sustainable, educational and tourist accessibility of the lobelia lakes & $\mathrm{B}$ \\
\hline & WaM & Development and modernization of waste recycling infrastructure & B CC Kw L \\
\hline & & Dry fermentation for separately collected green waste & St \\
\hline \multirow[t]{6}{*}{ SM } & Ed & Dissemination of preschool education & CC S SG \\
\hline & & Improving the efficiency of outdoor lighting systems & $\mathrm{S}$ \\
\hline & & $\begin{array}{l}\text { Improving energy efficiency by thermal modernization of public } \\
\text { facilities }\end{array}$ & B L M S \\
\hline & & as above + improving municipal heating networks & M S \\
\hline & & as above + improving sources of heat and energy & L SG \\
\hline & & as above + development of renewable energy sources & $\mathrm{CC}$ \\
\hline \multirow[t]{2}{*}{$?$} & WoM & Small retention of the Bibrowa river & $\mathrm{K}$ \\
\hline & En & $\begin{array}{l}\text { Construction and modernization of heat sources and connections. } \\
\text { networks and substations }\end{array}$ & $\mathrm{CC} \mathrm{Kw} \mathrm{SG}$ \\
\hline
\end{tabular}

FUAs / ITA: B - Bytów, CC - Chojnice - Człuchów, K - Kościerzyna, Kw - Kwidzyn, L Lębork, M - Malbork, S - Słupsk, SG - Starogard Gdański.

Source: own elaboration based on data of the Marshall Office of the Pomeranian Voivodeship [2014]. 
Table 3. Number and share of projects in the Pomeranian Voivodeship according to integrating factors

\begin{tabular}{|l|c|c|}
\multicolumn{1}{|c|}{ Integrating factors } & $\begin{array}{c}\text { Number } \\
\text { of projects }\end{array}$ & $\%$ \\
\hline Spatial extent of the item to which a project is relating & 2 & 3.3 \\
\hline Network - systemic relations & 16 & 26.2 \\
\hline Range of service - center (central functions) & 11 & 18.0 \\
\hline Range of influence - others (ex-resource base of the object) & 7 & 9.8 \\
\hline Specialized contractor & 6 & 24.6 \\
\hline The same type of project & 15 & 6.6 \\
\hline Difficult to discover & 4 & 100.0 \\
\hline Total & 61 & 9.5 \\
\hline
\end{tabular}

Source: authors' own elaboration based on Marshall Office of the Pomorskie Voivodeship [2014].

Table 4. Number and share of projects in the Pomeranian Voivodeship according to subject

\begin{tabular}{|l|c|r|}
\hline \multicolumn{1}{|c|}{ Subject } & $\begin{array}{c}\text { Number } \\
\text { of projects }\end{array}$ & $\%$ \\
\hline Education & 5 & 8.2 \\
\hline Health (including E-health -4 projects) & 11 & 18.0 \\
\hline ICT & 1 & 1.6 \\
\hline Social economy, vocational activation, social activation & 5 & 8.2 \\
\hline Transport & 9 & 14.8 \\
\hline Energy efficiency, incl. thermal energetics, thermomodernization & 15 & 24.6 \\
\hline Technical infrastructure - waste management & 5 & 8.2 \\
\hline Water management & 6 & 9.8 \\
\hline Nature and landscape protection & 1 & 1.6 \\
\hline Space & 1 & 1.6 \\
\hline Tourism, recreation & 2 & 3.3 \\
\hline Total & 61 & 100.0 \\
\hline
\end{tabular}

Source: authors' own elaboration based on Marshall Office of the Pomeranian Voivodeship [2014].

Negotiations with FUAs certainly led to the integration of the local policies and elimination from the race for the EU funds projects which were competing with each other. In some cases, however, the "urban" nature or integrating factor of these investments is doubtful. An example of such a project can be "Small retention of the Bibrowa river" in Kościerzyna FUA. The project is a solution in the local scale and it has been included in the list rather due to the division of allocation established between local partners than a possibility of achieving the synergic effect. In the field of water management in small FUAs one can also indicate positive examples. Among those are projects on the Liwa river (Kwidzyn FUA) and the Wierzyca river (Starogard FUA). The projects will not only contribute to the regulation of the water situation in the areas of several municipalities, but most urbanized areas will have a new space recreation. 


\section{Conclusions}

After the analysis, the following conclusions can be drawn:

1. For the effective implementation of its regional operational programme $\mathrm{PV}$ is introducing integrated territorial approach for the majority of urbanized areas. However, a special formula of negotiated ITA has been used in the case of smaller centres, which is more liberal and flexible than ITI.

2. In $95 \%$ of the negotiated projects integrating factors can be identified (as hypothesis) and classified.

3. Planning integrated development of the FUAs has a positive impact on raising awareness of the need of cooperation. It may also strengthen the efficiency of multilevel governance processes. Integrated projects may restrict the costs of the investments and contribute to the optimization of the investment policy. It has been also pointed out by Ratusznik and Struś [2014].

It would be advisable to undertake following actions in the future:

1. To continue research on development of FUAs in Poland - extending study after the approval of integrated projects in other regions and in other country;

2. To discuss the delimitation issue - as the projects related to the central functions in core area (hospitals, universities) serve usually much greater the area than FUA - the whole poviat or even more.

\section{References}

ESPON, 2007, Study on Urban Functions. Final report.

Europe 2020: A strategy for smart, sustainable and inclusive growth, 2010, European Commission, Brussels.

Frankowski J., Szmytkowska M., 2015, Regionalne zróżnicowanie nowych partnerstw miejskich w Polsce, [in:] Zarządzanie Publiczne, no. 2(30), pp. 131-150.

Koncepcja Przestrzennego Zagospodarowania Kraju 2030, 2011, Ministerstwo Rozwoju Regionalnego, Warszawa.

Miliony na rozwój Kościerzyny, 2014, http://kasiaknopik.blog.onet.pl/miliony (access 1.06.2015).

Noworól A., Domański B., 2013, Cele, zasady i instrumenty polityki miejskiej woj. małopolskiego, Studia KPZK, no. 153, pp. 159-162.

Obrębalski M., 2014, Kontrowersje wokót zintegrowanych inwestycji terytorialnych, Prace Naukowe Uniwersytetu Ekonomicznego we Wrocławiu, no. 333, pp. 63-70.

Ratuszniak I., Struś M., 2014, Zintegrowane inwestycje terytorialne jako instrument rozwoju obszarów wiejskich na przyktadzie aglomeracji watbrzyskiej, Roczniki Naukowe Stowarzyszenia Ekonomistów Rolnictwa i Agrobiznesu, no. 16(3). pp. 247-253.

Regulation No 1303/2013 of the European Parliament and of the Council of 17 December 2013, European Commission.

Rosenkiewicz K., 2012, Obszary funkcjonalne jako nowa kategoria polityki regionalnej i polityki przestrzennej w Polsce, [in:] P. Churski (ed.), Praktyczne aspekty badań regionalnych - varia, Vol. V, Seria Rozwój Regionalny i Polityka Regionalna, no. 17-18, Poznań, pp. 71-78.

Słodowa-Hełpa M., 2013, Wyzwania stojace przed polskim samorzadem lokalnym $w$ perspektywie 2014-2020, Studia Oeconomica Posnaniensia, no. 1(6), pp. 32-57. 
Szafranek E., 2015, Zintegrowane inwestycje terytorialne jako narzędzie budowy potencjalu obszarów funkcjonalnych. Przykład kędzierzyńsko-kozielskiego subregionalnego obszaru funkcjonalnego, Prace Naukowe Uniwersytetu Ekonomicznego we Wrocławiu, no. 392, pp. 109-118.

Województwo Pomorskie, http://strategia2020.pomorskie.eu/res/strategia2020/ZPT/zpt_parafowanie 160714_final.pdf (access 2.11.2014).

Zakrzewska-Półtorak A., 2013, Zintegrowane inwestycje terytorialne jako nowe narzędzie wspierania wspótpracy jednostek samorzadu terytorialnego - przypadek wrocławskiego obszaru funkcjonalnego, Biblioteka Regionalisty, no. 13, pp. 267-276.

Zasady realizacji Zintegrowanych Inwestycji Terytorialnych w Polsce, 2013, Min. Rozwoju, http:// samorzad.pap.pl/depesze/redakcyjne.fundusze_unijne/140615/ZIT-na-Pomorzu--Wladzeregionu-stawiaja-na-rozwoj-malych-miast- (access 25.11.2014). 